\title{
THE ROLE OF RESISTIN IN THE GENESIS OF METABOLIC DISORDERS IN PATHOLOGICAL PREGNANCY
}

\author{
S. O. OSTAFIICHUK \\ Ivano-Frankivsk National Medical University, Ukraine; \\ e-mail: svitlana.ostafijchuk@gmail.com
}

Received: 12 March 2019; Accepted: 13 August 2019

\begin{abstract}
Pathological gestational weight gain (GWG) is a risk factor for obstetric and perinatal complications. High metabolic activity of adipose tissue and the placenta during pregnancy manifests as an increased production of adipokines that are involved in glucose regulation and insulin sensitivity. The aim of this study was to determine the role of resistin in the genesis of metabolic disorders in pathological GWG pregnancies. The 163 pregnant women were examined in the study: 97 (59.5\%) had normal, 18 (11.0\%) had insufficient and 48 (29.4\%) had excessive prepregnancy weight and obesity. GWG was the recommended level in $56(34.4 \%)$, insufficient in 33 (20.2\%), and excessive in 74 (45.4\%) women. Anthropometry was performed in each trimester of pregnancy, the weight gain was measured, and the percentage of body fat mass, concentrations of resistin, glucose, insulin, and the HOMA-IR were evaluated. Positive associations were found between hyperresistinemia in the second trimester of pregnancy, and subsequent weight gain $(r=0.27, P=0.0006)$, percentage of body fat mass $(r=0.93, P=0.000)$ and insulin resistance $(r=0.89, P=0.000)$ in late pregnancy; these associations were especially evident in excessive GWG. Determination of predictors of insulin resistance, associated with endocrine activity of adipose tissue, such as the adipokine resistin, in the second trimester of pregnancy may help to predict the severity of metabolic shifts during pregnancy and the risk of developing obstetric and perinatal complications.
\end{abstract}

Keywords: gestational weight gain, resistin, glucose, insulin resistance.

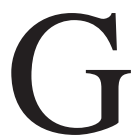

estational weight gain (GWG) reflects numerous endocrine and metabolic changes that occur in the maternal body during physiological adaptation to pregnancy, fetal energy supply and preparation for lactation [1]. Pathological weight gain is considered to be a significant and independent risk factor for obstetric and perinatal complications such as preeclampsia, gestational diabetes, and macrosomia, and increases operative delivery and the development of overweight and obesity after delivery [2]. Adipose tissue, as an endocrine organ, synthesizes biologically active substances, adipokines (leptin, adiponectin, resistin, plasminogen-1 activator inhibitor, tumor necrosis factor- $\alpha$, interleukin-6) that play direct roles in the processes of glucose metabolism regulation, tissue sensitivity to insulin, and systemic inflammation [3]. The role of adipokines in the mechanism of development of metabolic disorders in obstetric complications is a subject of active study in the scientific literature.

Resistin is a peptide hormone with a molecular weight of $12.5 \mathrm{kDa}$. In mice, the synthesis of resistin is restricted to adipocytes. However, in humans, adipocytes, pancreatic islets, mononuclear cells and placenta can synthesize this protein [4]. Resistin impairs glucose consumption by adipocytes, increases plasma glucose concentrations, and thus reduces insulin sensitivity [5]. In non-pregnant women, resistin levels are higher in individuals with obesity [6]. Costa et al. proved that during pregnancy, the placenta is an additional source of resistin, which is mainly synthesized in trophoblast cells. The authors emphasized the important role of this adipokine in the processes of the periimplantic period, such as the

(C) 2019 Ostafiichuk S. O. This is an open-access article distributed under the terms of the Creative Commons Attribution License, which permits unrestricted use, distribution, and reproduction in any medium, provided the original author and source are credited. 
invasion and proliferation of trophoblast, and angiogenesis, in order to achieve normal placement and progression of pregnancy [7].

It is established in the literature, that the resistin concentration in plasma of pregnant women exceeds the level in the absence of pregnancy $[8,9]$. However, the results of the dynamics of this hormone during pregnancy are controversial. Haugen et al. and Nien et al. postulated a significant increase of plasma resistin concentration between 11 and 14 weeks of gestation compared with non-pregnant women, a positive relationship between the elevation of this hormone and duration of pregnancy, and the probable increase of this adipokine in late pregnancy compared with the first trimester [4, 10]. However, no statistically significant association in resistin concentration between non-pregnant women and the first and second trimesters was found by Chen et al., but these authors did observe that the level of resistin before delivery significantly exceeded the levels at the beginning and in the middle of pregnancy [8]. To date there are no published reports in the literature devoted to the study of the plasma resistin level in women with different body weight gain during pregnancy.

The aim of this study was to determine the role of resistin in the genesis of metabolic disorders in pathological GWG pregnancies.

\section{Materials and Methods}

We studied 163 pregnant women who visited antenatal clinics in Ivano-Frankivsk, Ukraine during 2016-2018. Patients who were under 18 years old, diagnosed with multiple pregnancies, with term of labor up to 37 weeks, or severe chronic somatic diseases were excluded from the study. All women signed informed consent forms to participate in the study. The research design was approved by the Ethics Committee of the Ivano-Frankivsk National Medical University in Ivano-Frankivsk, Ukraine (protocol № 93/16 dated 01.12.2016). This study is a part of the complex scientific research work "Clinical-pathogenetic ways of reducing the frequency of reproductive health disorders and perinatal complications of women in Prykarpattya” (state registration № 0114U004747).

The mean age of patients was $28.3 \pm 5.1$ years (95\% Cl 27.5-29.1). Pregnancy management with nutrition and physical activity recommendations was performed in accordance with existing Ukrainia guidelines [11]. The weight of the patients was measured using electronic scales to the nearest $0.1 \mathrm{~kg}$ (Esperanza EBS002K, Poland). Measurement of height was performed using a digital stadiometer with an accuracy of $1.0 \mathrm{~cm}$ (RP-2000, Kiev, Ukraine). BMI was calculated according to the Quetelet formula (devised by Belgian scientist Adolphe Quetelet in the 1830s) as the ratio of body mass $(\mathrm{kg})$ to the square of body height $\left(\mathrm{m}^{2}\right)$. Information about body weight of the women before pregnancy was obtained by patient questioning and medical records. Anthropometry was performed during 9-11, 22-24 and 37-39 weeks of gestation. GWG was estimated by calculating the difference between the weight before labor and prepregnancy weight. Percentage of body fat mass was determined using spectral bioimpedansometry (with the use of "Diamant-aist" analyzer KM-AP-01, St. Petersburg, Russia) connected to a computer [12]. Quantitative determination of resistin in blood serum was performed using enzyme immunodetection (Mediagnost, kat. № E50 Resistin-ELISA US RUO E50 030113/6, Canada). The level of glucose in blood plasma was determined according to standard methods [13] in the central clinical-diagnostic laboratory of the Regional Perinatal Centre (Ivano-Frankivsk). Blood insulin content in blood serum was determined using the enzyme immunodetection method (Insulin Test System-2425-300, Monobind Inc., Lake Forest, CA, USA) with the following calculation of the insulin resistance index (homeostatic model assessment of insulin resistance, HOMA-IR) by the formula: fasting glucose level (mmol/l) $\mathrm{x}$ fasting insulin level $(\mu \mathrm{M} / \mathrm{ml}) / 22.5$.

Statistical analyses were performed using Statistica 6.0 software (StatSoft Inc.,USA), and the Microsoft Excel statistical analysis package (Microsoft Corp., Redmond, WA, USA). The following were calculated: average arithmetic mean $(M)$, mean standard deviation $(m)$, confidence interval $(\mathrm{Cl})$, correlation coefficient $(r)$, and the reliability of the difference between the results of the study $(P)$. The difference between compared values was considered to be significant at $P<0.05$.

\section{Results and Discussion}

Of the 163 women in the study, $97(59.5 \pm 3.8 \%)$ were nulliparous and $66(40.5 \pm 3.8 \%)$ were multiparous women. All women had childbirth at full-term pregnancies (39.1 \pm 1.3 weeks $(95 \% \mathrm{Cl} 38.9-39.3)$ ).

The prepregnancy body mass index (BMI) was the recommended level in 97 patients $(59.5 \pm 3.8 \%)$, 
insufficient in $18(11.0 \pm 2.5 \%)$, and overweight/ obese in 48 patients $(29.4 \pm 3.6 \%)$, based on the recommendations of the Institute of Medicine (IOM) in the United States (2009) [14] and the Order of the Ministry of Health of Ukraine № 417 (2011) [11]. Overweight and obese women were combined into one group (overweight/obese) for statistical analysis (BMI $\geq 25 \mathrm{~kg} / \mathrm{m}^{2}$ ), because of the absence of a significant difference between the results in these groups. At the end of pregnancy the recommended GWG was in 56 patients $(34.4 \pm 3.7 \%)$, inadequate in $33(20.2 \pm 3.1 \%)$, and excessive in 74 patients $(45.4 \pm 3.9 \%)$, based on the published guidelines $[11,14]$.

In the group of women with overweight/obese prepregnancy BMI, the plasma resistin concentration in the first trimester significantly exceeded the normative limits determined for non-pregnant women, but only in this group $(P<0.05)$. A statistically significant association was found between the level of resistin and GWG in the second $(r=0.27, P=0.001)$ and third ( $r=0.52, P=0.000)$ trimesters, regardless of the final weight gain and the absence of significant correlation in the first trimester $(P>0.05)$. There was also a positive relationship between the elevation of plasma resistin during 22-24 weeks (i.e., second trimester) and the subsequent GWG in late pregnancy (i.e., third trimester) $(r=0.27, P=0.0006)$ (Fig. 1). However, later the statistically significant difference was only in women with excessive GWG in which the plasma resistin level before childbirth was 1.4fold higher $(P<0.05)$ than in the first trimester and 1.2-fold higher $(P<0.05)$ compared with the recommended GWG.

The changes of plasma resistin levels in pregnant women with different prepregnancy BMI were analyzed. A significant increase of plasma resistin levels was found in the second $(P<0.05)$ and third $(P<0.02)$ trimesters in women with recommended prepregnancy BMI independent of GWG. However, the resistin level was 1.3-fold higher during 2224 weeks and 1.2-fold higher during 37-39 weeks $(P<0.05$ in both cases in women with excessive GWG compared to women with the recommended GWG (Fig. 2).

In the group of women with the recommended prepregnancy BMI a positive correlation was found between the plasma resistin concentration and GWG in the second $(r=0.83, P=0.000)$ and third trimesters $(r=0.89, P=0.000)$. It is important to

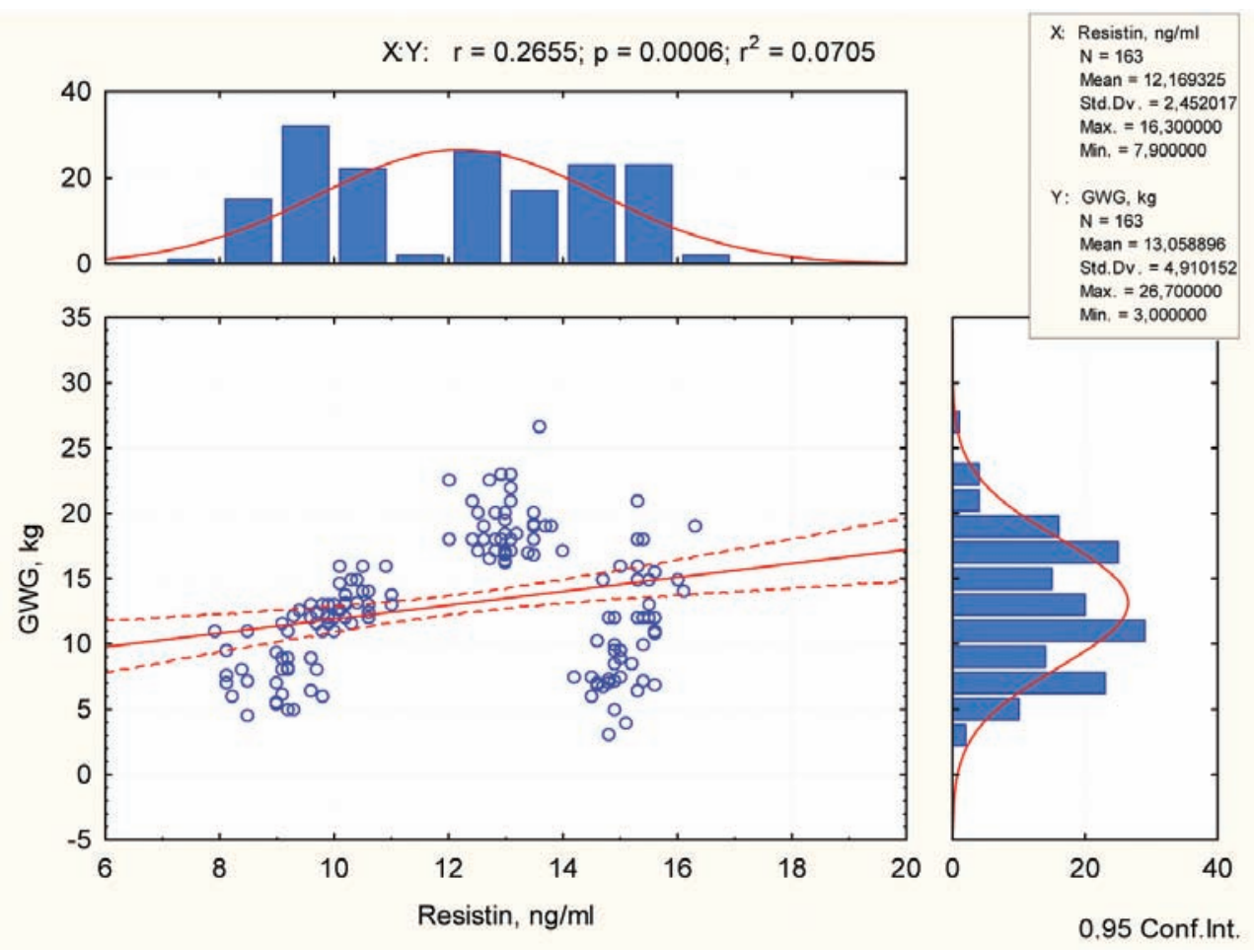

Fig. 1. Relationship of plasma resistin concentration in the second trimester and gestational weight gain $(G W G)$ in the third trimester 


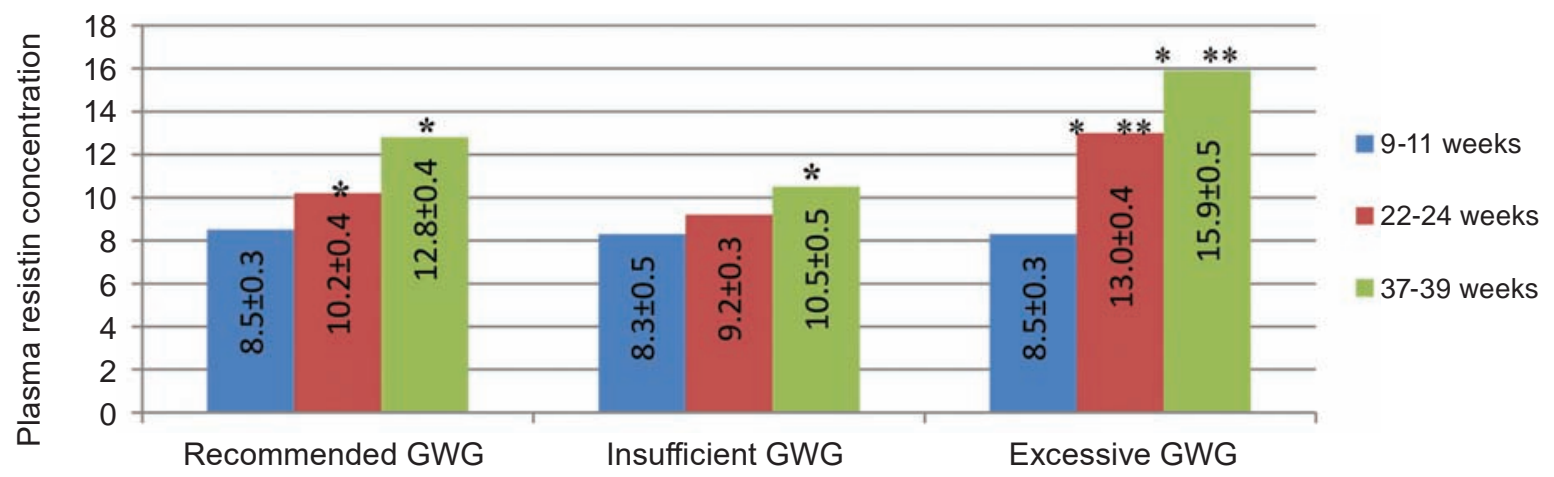

Fig. 2. Dynamics of plasma resistin concentration $(\mathrm{ng} / \mathrm{ml})$ in pregnant women with the recommended prepregnancy BMI. $* P<0.05$ for comparison with the first trimester, $* * P<0.05$ for comparison with recommended $G W G$

note that there is a strong direct correlation between the elevation of resistin in the middle of pregnancy and the subsequent increase in weight at later stages $(r=0.88, P=0.000)$.

In the group of women with insufficient prepregnancy BMI, there was monotypic dynamics of elevation of plasma resistin level only at the end of pregnancy regardless of GWG $(P<0.05)$, but there was no significant difference in comparison with women who had the recommended prepregnancy BMI $(P>0.05)$ (Fig. 3).

In women with overweight/obese prepregnancy BMI, in the first trimester the plasma resistin concentration was significantly higher (1.7-fold, $P<0.001)$ compared to women with the recommended prepregnancy BMI. In this group of pregnant women, a positive correlation was found between the concentration of resistin and GWG in the second ( $r=0.51, P=0.0001)$ and third trimesters $(r=0.52, P=0.0001)$. A statistically significant relationship was also found between hyperresistinemia in the middle of pregnancy and GWG before delivery $(r=0.53, P=0.000)$. There were no significant differences of resistin with the duration of pregnancy in women with insufficient GWG $(P>0.05)$ (Fig. 4). In the overweight/obese prepregnancy group with the recommended and excessive GWG, the resistin level was higher in the third trimester than during the earlier terms $(P<0.05$ and $P<0.02$, respectively), but there were no significant differences among women with the recommended prepregnancy BMI $(P>0.05)$. It should be noted that at the end of pregnancy, the percentage rise of the resistin level in pregnant women with overweight/obese prepregnancy BMI was significantly lower than that of pregnant women with the recommended prepregnancy BMI $(P<0.05)$.

An analysis of the association between the plasma resistin concentration and fat component of GWG indicates a direct correlation between hyperresistinemia and increase in the percentage of body fat mass in all pregnant women in the second $(r=0.86$,

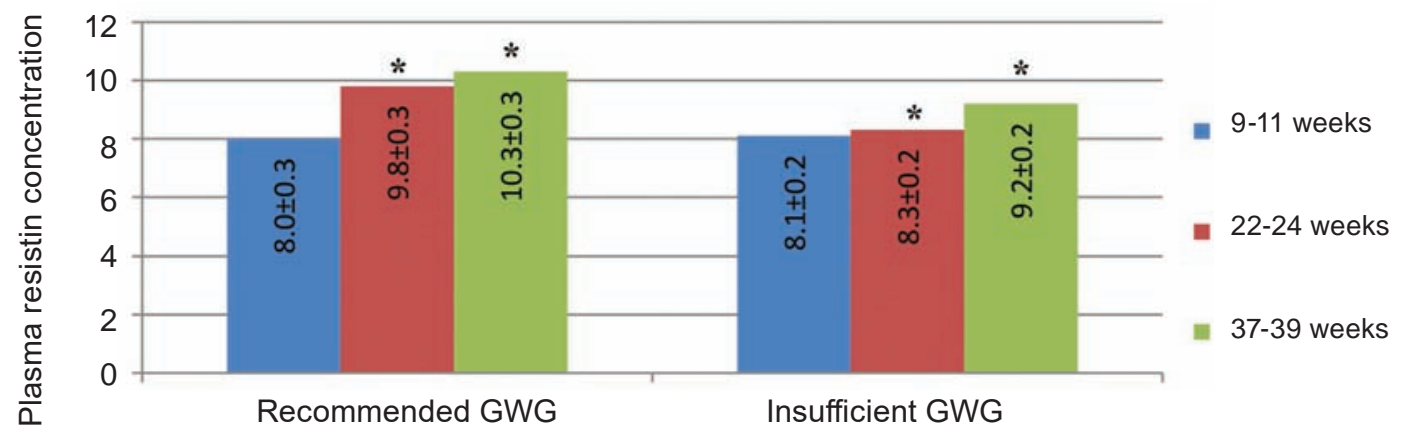

Fig. 3. Dynamics of plasma resistin concentration $(\mathrm{ng} / \mathrm{ml})$ in pregnant women with insufficient prepregnancy $B M I . * P<0.05$ in comparison with the first trimester 


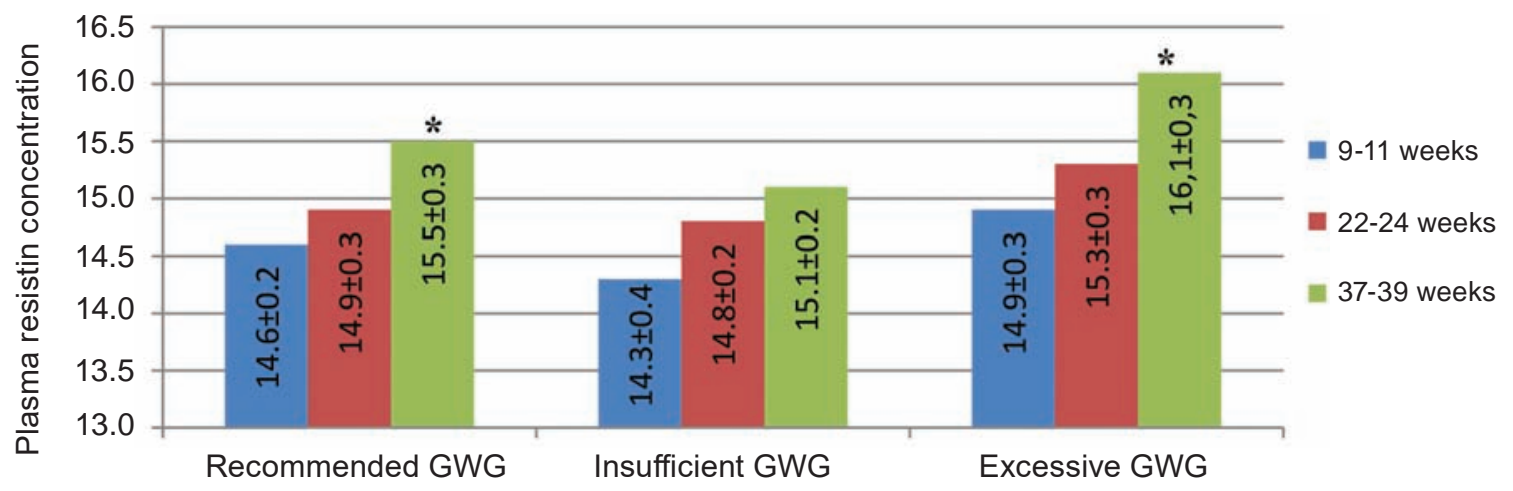

Fig. 4. Dynamics of plasma resistin concentration $(\mathrm{ng} / \mathrm{ml}$ ) in pregnant women with overweight/obese prepregnancy $B M I . * P<0.05$ in comparison with the first trimester

$P=0.000)$ and third trimesters $(r=0.82, P=0.000)$. It is important to note that the elevation of the resistin level in the second trimester significantly correlated with the subsequent increase in the percentage of body fat mass until the end of pregnancy $(r=0.93$, $P=0.000$ ) (Fig. 5).

It is known that pregnancy is characterized by a state of insulin resistance (IR), mainly due to the increased production of placental hormones, for adequate fetal energy supply. In the scientific literature, the role of adipose tissue and adipokines in the induction and regulation of IR in non-pregnant and pregnant women with obesity was demonstrated $[15,16]$. The authors proved the correlation between the plasma level of resistin and IR. According to the rapid growth of body fat mass, as the most labile component of GWG, the relationship of the plasma resistin concentration and the HOMA-IR value as a model of IR determination was evaluated. A statistically significant relationship was found between the resistin level and the HOMA-IR value in the second $(r=0.83, p=0.000)$ and third $(r=0.84, P=0.000)$
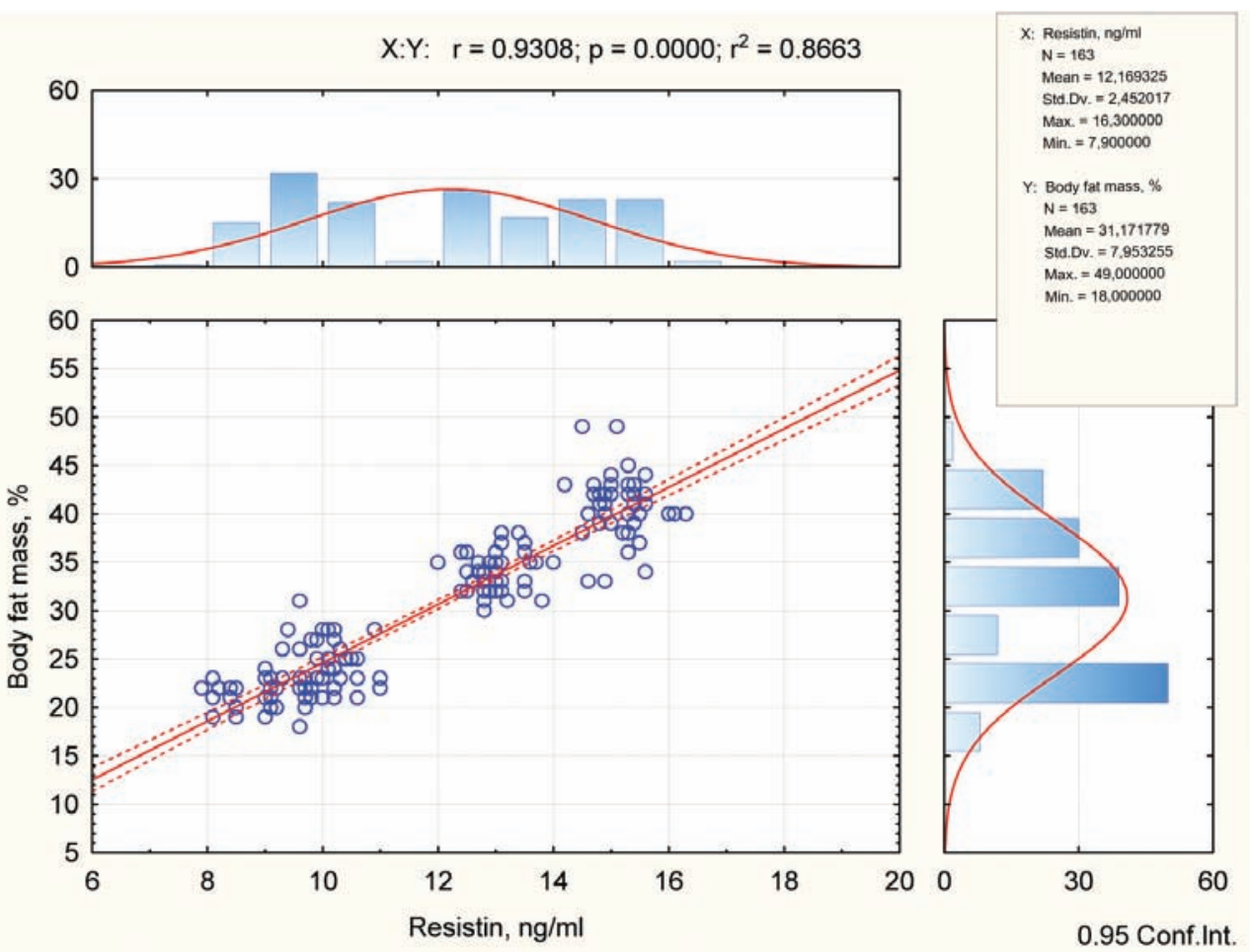

Fig. 5. Relationship of the plasma resistin concentration in the second trimester and the percentage of body fat mass in the third trimester 

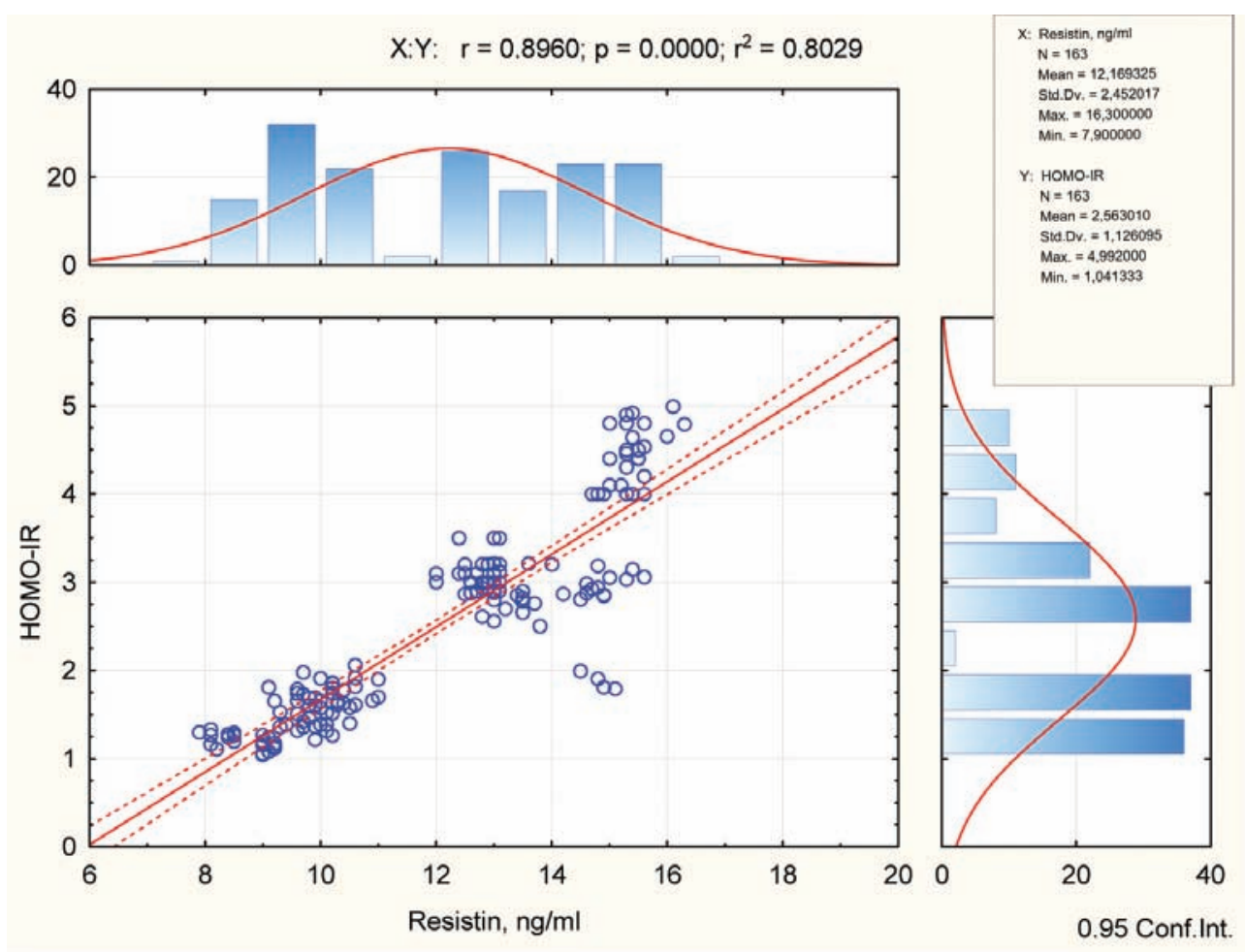

Fig. 6. Relationship between the plasma resistin concentration in the second trimester and the HOMA-IR value in the third trimester. HOMA-IR, homeostatic model assessment of insulin resistance.

trimesters, regardless of prepregnancy body weight. There was also a significant correlation between hyperresistinemia in the second trimester and IR in late pregnancy $(r=0.89, P=0.000$ ) (Fig. 6).

Our results corroborate the data obtained by Nien et al. and Edalat et al., who have described the elevation of IR in pregnant women under the influence of adipokines, particulary resistin [10, 17]. However, our findings are in contrast to those of Haugen et al., who did not confirm a relationship between the plasma resistin concentration and IR, but these authors examined normal weight women without accounting for the GWG level [4].

Thus, associations between an elevated plasma resistin concentration and the GWG, percentage of body fat mass and HOMA-IR in all pregnant women, regardless of the prepregnancy BMI were demonstrated. But the most progressive dynamics of the resistin level increase was observed in pregnant women with the recommended prepregnancy BMI but excessive GWG. In these women, the progress of hyperresistinemia during pregnancy was more intense compared with pregnant women who had overweight/obese prepregnancy BMI; before labor, the restin level of these lower prepregnancy BMI women reached that of these higher prepregnancy BMI women $(15.9 \pm 0.5 \mathrm{ng} / \mathrm{ml}$ versus $16.1 \pm 0.4 \mathrm{ng} /$ $\mathrm{ml}$, respectively, $P>0.05$ ). IR during pregnancy was accompanied by a marked increase in the fat depot, so it could be assumed that fat tissue plays a role in the initiation and regulation of the gestational IR. Our findings of increased plasma resistin concentration with the progression of pregnancy, especially with excessive GWG, confirm the association between adipokines and tissue IR during pregnancy.

Thus, these results expand the current knowledge about the role of resistin in the genesis of metabolic disorders in pathological GWG pregnancies. Hyperresistinemia in the second trimester of pregnancy is associated with a subsequent later weight gain, an increased percentage of body fat mass and increased tissue IR, which is especially pronounced in excessive GWG. Identification of predictors of IR, associated with endocrine activity of adipose tissue, such as the adipokine resistin, in the second trimester of pregnancy can help predict the severity of metabolic disorders during pregnancy and the risk of developing obstetric and perinatal complications. 
РОЛЬ РЕЗИСТИНУ В ГЕНЕЗІ

МЕТАБОЛІЧНИХ РОЗЛАДІВ

ЗА ПАТОЛОГІЧНОЇ ВАГІТНОСТІ

\section{C. О. Остафійчук}

\author{
Івано-Франківський національний \\ медичний університет, Україна; \\ e-mail: svitlana.ostafijchuk@gmail.com
}

Патологічне гестаційне збільшення маси тіла (ГЗМТ) є фактором ризику акушерських та перинатальних ускладнень. Висока метаболічна активність жирової тканини та плаценти під час вагітності проявляється посиленою продукцією адипокінів, які беруть участь у регуляції рівня глюкози та чутливості тканин до інсуліну. Метою роботи було встановлення ролі резистину в генезі метаболічних розладів за патологічного гестаційного приросту у вазі. Обстежено 163 вагітні жінки: 97 (59,5\%) з нормальною, 18 $(11,0 \%)$ - 3 недостатньою та $48(29,4 \%)$ - 3 надлишковою прегравідарною вагою та ожирінням. ГЗМТ діагностовано у 56 (34,4\%), недостатне у 33 (20,2\%), а надлишкове у 74 (45,4\%) пацієнток. У кожному триместрі вагітності проводили антропометрію, діагностували надбавку у вазі, відсоток жирової маси тіла, концентрацію резистину, глюкози, інсуліну, НOMO-IR. Виявлено кореляцію між підвищеним рівнем резистину в другому триместрі вагітності, подальшою надбавкою у вазі $(r=0,27, P=0,0006)$, відсотком ЖМТ $(r=0,93, P=0,000)$ та посиленням резистентності тканин до інсуліну $(r=0,89, P=0,000)$ в третьому триместрі, що особливо виражено за надлишкового ГЗМТ. Діагностування предикторів інсулінорезистентності, асоційованих із жировою тканиною, зокрема адипокіну резистину, в другому триместрі вагітності може слугувати прогнозом щодо тяжкості перебігу метаболічних зрушень під час вагітності та ризику розвитку акушерських та перинатальних ускладнень.

К л ю чо в і с лов а: гестаційне збільшення маси тіла, адипокіни, резистин, інсулінорезистентність.

\section{References}

1. Şengül Ö, Dede S. Maternal and Fetal Carbohydrate, Lipid and Protein Metabolisms. Eur J Gen Med. 2014; 11(4): 299-304.

2. Goldstein RF, Abell SK, Ranasinha S, Misso ML, Boyle JA, Harrison CL, Black MH, Li N, Hu G, Corrado F, Hegaard H, Kim YJ, Haugen M, Song WO, Kim MH, Bogaerts A, Devlieger R, Chung JH, Teede HJ. Gestational weight gain across continents and ethnicity: systematic review and meta-analysis of maternal and infant outcomes in more than one million women. BMC Med. 2018; 16(1): 153.

3. Chabanova NB, Mataev SI, Vasilkova TN, Troshina IA. Metabolic disorders in adipocytokine imbalance and gestational complications. Obes Metab. 2017; 14(1): 9-16. (In Russian).

4. Haugen F, Ranheim T, Harsem NK, Lips E, Staff AC, Drevon CA. Increased plasma levels of adipokines in preeclampsia: relationship to placenta and adipose tissue gene expression. Am J Physiol Endocrinol Metab. 2006; 290(2): E326-E333.

5. Bao W, Baecker A, Song Y, Kiely M, Liu S, Zhang C. Adipokine levels during the first or early second trimester of pregnancy and subsequent risk of gestational diabetes mellitus: A systematic review. Metabolism. 2015; 64(6): 756-764.

6. Ozias MK, Li S, Hull HR, Brooks WM, Carlson SE. Relationship of circulating adipokines to body composition in pregnant women. Adipocyte. 2014; 4(1): 44-49.

7. Costa MA. The endocrine function of human placenta: an overview. Reprod Biomed Online. 2016; 32(1): 14-43.

8. Chen D, Dong M, Fang Q, He J, Wang Z, Yang X. Alterations of serum resistin in normal pregnancy and pre-eclampsia. Clin Sci. 2005; 108(1): 81-84.

9. Jiang S, Teague AM, Truggestad JB, Lyons T, Chernausek S. Regulation and role of human resistin in diabetes during pregnancy. Diabetes. 2018; 67(Suppl 1): 1401. 
10. Nien JK, Mazaki-Tovi S, Romero R, Kusanovic JP, Erez O, Gotsch F, Pineles BL, Friel LA, Espinoza J, Goncalves L, Santolaya J, Gomez R, Hong JS, Edwin S, Soto E, Richani K, Mazor M, Hassan SS. Resistin: a hormone which induces insulin resistance is increased in normal pregnancy. J Perinat Med. 2007; 35(6): 513-521.

11. Order of the Ministry of Health of Ukraine No. 417 dated July 15, 2011 "Methodological recommendations for the organization of ambulatory obstetric and gynecological care”. (In Ukrainian).

12. Staelens AS, Vonck S, Molenberghs G, Malbrain ML, Gyselaers W. Maternal body fluid composition in uncomplicated pregnancies and preeclampsia: a bioelectrical impedance analysis. Eur J Obstet Gynecol Reprod Biol. 2016; 204: 69-73.

13. Clinical laboratory diagnostics. National leadership. Ed. Dolgov VV. In 2 vol. 2013; 1: 934 p. (In Russian).

14. IOM, Weight Gain During Pregnancy: Reexamining the Guidelines. Institute of Medicine and National Research Council of the National Academies, Committee to Reexamine
IOM Pregnancy Weight Guidelines, Food and Nutrition Board on Children, Youth, and Families, ed. Rasmussen KM. and Yaktine AL. 2009, Washington, D.C.: The National Academies Press.

15. Vernini JM, Moreli JB, Costa RA, Negrato CA, Rudge MV, Calderon IM. Maternal adipokines and insulin as biomarkers of pregnancies complicated by overweight and obesity. Diabetol Metab Syndr. 2016; 8(1): 68.

16. Solis-Paredes M, Espino Y Sosa S, EstradaGutierrez G, Nava-Salazar S, Ortega-Castillo V, Rodriguez-Bosch M, Bravo-Flores E, EspejelNuñez A, Tolentino-Dolores M, GaonaEstudillo R, Martinez-Bautista N, PerichartPerera O. Maternal and fetal lipid and adipokine profiles and their association with obesity. Int $J$ Endocrinol. 2016; 2016: 7015626.

17. Edalat B, Sharifi F, Badamchizadeh Z, Hossein-Nezhad A, Larijani B, Mirarefin M, Fakhrzadeh H. Association of metabolic syndrome with inflammatory mediators in women with previous gestational diabetes mellitus. J Diabetes Metab Disord. 2013; 12(1): 8. 